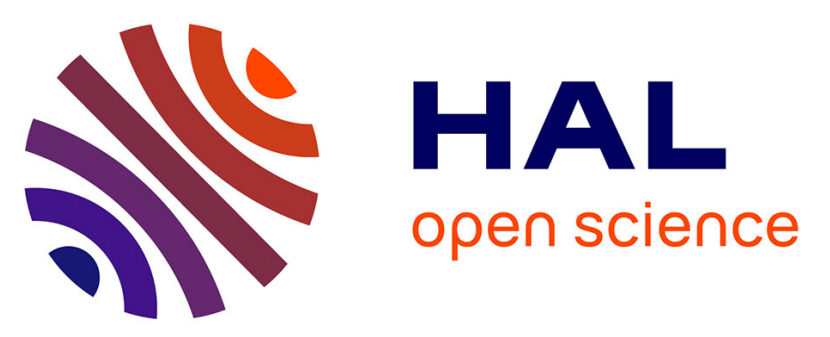

\title{
Variations in reproductive strategy of the silver Arowana, Osteoglossum bicirrhosum Cuvier, 1829 from four sub-basins of the Peruvian Amazon
}

F. Duponchelle, A. Ruiz Arce, A. Waty, A. Garcia-Vasquez, J.-F. Renno, F. Chu-Koo, C. Garcia-Davila, G. Vargas, S. Tello, A. Ortiz, et al.

\section{To cite this version:}

F. Duponchelle, A. Ruiz Arce, A. Waty, A. Garcia-Vasquez, J.-F. Renno, et al.. Variations in reproductive strategy of the silver Arowana, Osteoglossum bicirrhosum Cuvier, 1829 from four sub-basins of the Peruvian Amazon. Journal of Applied Ichthyology, 2015, 31 (S4), pp.19-30. 10.1111/jai.12973 . hal-01292011

\section{HAL Id: hal-01292011 \\ https: / hal.sorbonne-universite.fr/hal-01292011}

Submitted on 22 Mar 2016

HAL is a multi-disciplinary open access archive for the deposit and dissemination of scientific research documents, whether they are published or not. The documents may come from teaching and research institutions in France or abroad, or from public or private research centers.
L'archive ouverte pluridisciplinaire HAL, est destinée au dépôt et à la diffusion de documents scientifiques de niveau recherche, publiés ou non, émanant des établissements d'enseignement et de recherche français ou étrangers, des laboratoires publics ou privés. 
7 Manzanares Vásquez ${ }^{5}$, and J. Nuñez Rodriguez ${ }^{1,2}$

1 Laboratoire Mixte International - Evolution et Domestication de l'Ichtyofaune Amazonienne (LMI - EDIA).

2 Institut de Recherche pour le Développement (IRD), Unité Mixte de Recherche Biologie des Organismes et Ecosystèmes Aquatiques (UMR BOREA - MNHN, CNRS-7208, UPMC, UCBN, IRD-207), F-34394, Montpellier, France.

3 Instituto de Investigación de la Amazonía Peruana (IIAP), IquitosQuistococha, Perú.

4 Universidad Nacional Intercultural de la Amazonía - UNIA. Facultad de Ingeniería y Ciencias Ambientales

5 Instituto Nacional de Desarrollo (INADE). Proyecto Especial de Desarrollo Integral de la Cuenca del Putumayo (PEDICP). Iquitos, Peru.

The aim of this study was to assess the variability of reproductive characteristics of

27 the silver Arowana, Osteoglossum bicirrhosum, in four sub-basins of the Peruvian

28 Amazon: the Amazonas, Ucayali, Napo and Putumayo rivers. An illustrated, detailed

29 gonadal maturation scale is proposed for a clearer determination of the reproductive

30 status of male and female Arowana. The breeding season occurred during the dry

31 season and early rising waters in the Amazonas and Ucayali, whereas it was

32 restricted to the dry season in the Napo and Putumayo. A same female can reproduce

33 more than once during the breeding season. Age at maturity was reached during the 
34 second year, at sizes varying between $43-45 \mathrm{~cm}$ for males and $46-50 \mathrm{~cm}$ for females.

35 Important variations in fecundity were observed between fish of the four sub-basins,

36 whereas mean oocytes diameter and mass did not vary significantly, suggesting

37 differences in reproductive investment. Together with previously reported variations

38 of growth patterns in the same sub-basins, these results suggest the existence of

39 distinct populations in the Peruvian Amazon, with important consequences for

40 management and conservation, but also for future aquaculture development

41 programs.

\section{Introduction}

45 The silver Arowana, Osteoglossum bicirrhosum, is a relatively large ( $>1 \mathrm{~m}$ length),

46 laterally compressed fish of the archaic bony-tongued fish Order Osteoglossiforms

47 (Goulding, 1980), comprising, in South America, the blue Arowana, Osteoglossum

48 ferreirai Kanazawa 1966, and the species of the genus Arapaima spp., known as

49 pirarucu in Brazil and paiche in the other Amazonian countries. The silver Arowana

50 preferentially inhabits lentic waters of the Amazon, Rupununi and Oyapock rivers

51 (Goulding, 1980; Bayley and Petrere, 1989; Reis et al., 2003; Saint-Paul et al., 2000).

52 This species occupies a particular place in Amazonian fisheries as it is heavily

53 harvested both as an adult for human consumption and as a small juvenile (usually

54 still with its yolk sac) for the ornamental trade (Moreau and Coomes, 2006;

55 Alcantara et al., 2007). The Asian Arowanas (Sleropages spp.) or dragon fish,

56 closely resemble the Amazonian silver Arowana. These are very popular and sought

57 for pet fish in Asian markets, which has lead natural populations to be so

58 dramatically depleted that they have been listed under the Convention on 
59 International Trade in Endangered Species (CITES) Appendix I in 1975 (Moreau and

60 Coomes, 2006). Since then, the Amazonian cousin, O. bicirrhosum, has replaced

61 them in Asian markets and its exportation has increased alarmingly since the 1990s

62 (Tello and Canepa, 1991; Moreau and Coomes, 2006, 2007). Owing to its increasing

63 exploitation in Amazonia for ornamental purposes, the species is considered

64 threatened in Peru (Moreau and Coomes, 2006), it has already been placed on the

65 Red Book of Colombia (Mojica et al., 2002) and its trade for ornamental purposes is

66 prohibited in Brazil (Lima and Prang, 2008; Prang, 2008).

67 The reproductive biology of the silver Arowana is relatively well described since the

68 early studies of Goulding $(1980,1990)$ and Aragao (1989). Recently, patterns of

69 reproductive investment were further investigated in the Mamirauá Reserve

70 (Queiroz, 2008) and the potential role of male aggregations was explored (Verba et

71 al., 2014). In Peru, its reproductive characteristics were studied in one lake of the

72 Putumayo River (Cortegano et al., 2014) and further information also exists from

73 unpublished dissertations (Ayala, 2001; Tang and Gomez, 2005). Despite extensive

74 ornamental fisheries in almost all the distribution area of the species and growing

75 concern about its conservation, however, no assessment of the geographic variability

76 of reproductive traits has yet been attempted. Besides the obvious interest for

77 conservation and fisheries management, the knowledge of whether geographic

78 population may display significant variations in specific reproductive traits such as

79 the timing of maturation and egg production would be determinant for future

80 aquaculture development. Indeed, the production of Arowana juveniles in controlled

81 conditions (aquaculture) appears to be the most immediate alternative to extraction

82 of natural populations for ornamental purposes (Argumedo, 2005; Moreau and

83 Coomes, 2006). Choosing breeders from a population with higher relative fecundity 
84 (egg production per unit body mass), for example, might increase chances of success.

85 A recent study in the Peruvian Amazon demonstrated important variations in the

86 growth patterns of the silver Arowana in four sub-basins, suggesting the existence of

87 distinct populations, which might require independent management (Duponchelle et

88 al., 2012). The aim of the present study is to assess whether reproductive

89 characteristics also vary, and to which extent, between these four sub-basins of the

90 Peruvian Amazon.

92 Material and Methods

\section{$94 \quad$ Fish collection}

Fish were collected monthly between November 2006 and April 2009 at the

97 Iquitos and Requena markets for the Amazonas, Ucayali and Napo sub-basins

98 (Figure 1). Requena is an important market located on the lower Ucayali River and

99 Iquitos is the main landing market of the Peruvian Amazon, concentrating fishes

100 from the Amazonas, Ucayali, Marañon, Napo, Huallaga, Tigre, Putumayo, Nanay,

101 Yavari and Morona sub-basins (Garcia-Vasquez et al., 2009). For a better accuracy

102 on specimen provenance, fish (of the largest possible size range) were bought from

103 specific providers from each river basin for the Amazonas, Napo and Ucayali rivers.

104 For the Putumayo River, fish were bought monthly, from March 2008 to April 2009,

105 from local fishermen in El Estrecho and Huapapa communities (Figure 1). The sub-

106 basins were chosen on the basis of their hydrological cycle: the Amazonas and 107 Ucayali have very similar hydrological cycles; the Putumayo and Napo also have 108 similar hydrological cycles, but lag from about three months from that of the 
109 Amazonas-Ucayali. The availability and reliability of specimen's provenance was

110 also taken into account. Monthly means of water levels were provided by the SO-

111 HYBAM (Observation Service - Geodynamical, hydrological and biogeochemical

112 control of erosion/alteration and material transport in the Amazon basin) and

113 SENAMHI (Servicio Nacional de Meteoloría e Hidrología), Peru.

115 Biological sample analysis

117 A total of 951 specimens of $O$. bicirrhosum were analysed. On each fish, total length

$118\left(\mathrm{~T}_{\mathrm{L}}\right)$, standard length $\left(\mathrm{S}_{\mathrm{L}}\right)$ and body mass were measured to the nearest $\mathrm{mm}$ and $\mathrm{g}$,

119 respectively. Gonads were photographed and macroscopically checked for maturity

120 stage. On each fish, a gonad sample was preserved in Bouin's fluid for histological

121 analyses. Fixed gonads were further processed under classical histological methods

122 with Haematoxylin and Eosin staining for confirmation of macroscopic maturity

123 stages. A gonadal maturation scale was then established, based on the macroscopic

124 criteria detailed in Nuñez and Duponchelle (2009). Nevertheless, the proposed scale

125 also provides the equivalence with Brown-Petersen et al. (2011)'s terminology,

126 which was developed in an effort to standardize the confusing number of terms

127 referring to key phases of the reproductive cycle in fisheries science' literature.

128 The breeding season was estimated from the monthly proportions of females'

129 gonadal maturation stage "spawning capable" (Brown-Petersen et al., 2011). To

130 obtain a better representation of the annual cycle, data collected over the study period

131 were pooled for each river basin.

132 The average size at first sexual maturity $\left(\mathrm{L}_{\mathrm{m}}\right)$ is defined as the standard length

133 at which $50 \%$ of the individuals are at an advanced stage of the first sexual cycle 
134 during the breeding season (Legendre and Ecoutin, 1989). Practically, this is the size 135 at which $50 \%$ of the fish have reached stage 2 of the maturity scale for females and 136 males (Nuñez and Duponchelle, 2009). The mean SL at first maturity $\left(\mathrm{L}_{\mathrm{m}}\right)$ was 137 estimated by fitting the fraction of mature individuals per $50 \mathrm{~mm} \mathrm{~S}_{\mathrm{L}}$ intervals to a 138 logistic regression function weighted by the total number of individuals in each size 139 class (Barbieri et al., 1994; Duponchelle and Panfili, 1998):

$$
\% M=\frac{100}{1+e^{(-a \times(L-L m))}}
$$

141 where $\% \mathrm{M}=$ percentage of mature individual by size class, $\mathrm{L}=$ central value of

142 each size class, and a and $\mathrm{L}_{\mathrm{m}}=$ constants of the model.

143 The age at first sexual maturity $\left(\mathrm{A}_{\mathrm{m}}\right)$ was calculated from the von Bertalanffy growth 144 function (VBGF) as follows:

$$
A_{m}=\left(-\ln \left(1-\left(L_{m} / L_{\infty}\right)\right) / K\right)+t_{0}
$$

146 where $\mathrm{L}_{\mathrm{m}}$ is the size at first sexual maturity previously calculated and $t, \mathrm{~L}_{\infty}, \mathrm{K}$ and $\mathrm{t}_{0}$

147 the parameters of the VBGF obtained from Duponchelle et al. (2012) on the same 148 samples.

149 Batch fecundity (number of eggs to be potentially laid per spawning event, 150 resulting from the maturation of fully developed intra-follicular oocytes) and oocyte 151 diameter were estimated by image analysis (using NIH Image J software) from 152 whole gonads in final maturation stage (stage 3). As the oocytes were not exactly 153 circular in shape, the mean arithmetic diameter was used: $\sqrt{ }$ d.D, where $d$ is the 154 minimum diameter and $\mathrm{D}$ the maximum diameter of each oocyte. Oocyte mean mass 155 was calculated from each stage 3 gonads, by weighing 30 oocytes to the nearest $1560.001 \mathrm{~g}$. 
160 Differences in mean standard length and mass between sexes within each sub-basin

161 were tested with a t-test. Differences of mean standard length or mass between sub-

162 basins were tested with Kruskal-Wallis One Way Anova on ranks and Dunn's all

163 pairwise post-hoc tests.

164 For each sub-basin, logistic regression models provided an estimate of the $\mathrm{L}_{\mathrm{m}} \pm$

165 standard deviation (equation 1). Therefore, sizes at maturity between sexes or

166 geographic locations were compared using a classical Student t-test (degrees of

167 freedom calculated from the number of size classes).

168 Analysis of covariance (ANCOVA) was used to test for differences in the fecundity-

169 body mass relationships between geographic populations, using fecundity as the

170 dependent variable, body mass as the covariate, and geographic population as

171 categorical variable.

172 Comparisons of mean oocyte diameter and mass between geographic populations

173 were carried out using one-way ANOVA.

174 For all comparisons, when more than two pairwise-tests were performed, the

175 Bonferroni correction was applied to keep the experiment-wide error rate at the

176 desired $\alpha(0.05,0.01$ or 0.001$)$.

178 Results

180 A total of 290 specimens of $O$. bicirrhosum were analysed for the Amazonas, 276 for

181 the Ucayali, 145 for the Napo and 240 for the Putumayo (Figure 2a). Mean standard

182 lengths $\left(\mathrm{S}_{\mathrm{L}}\right)$ and masses did not differ among sexes in any population. There were,

183 however, significant differences in mean length (Kruskal-Wallis One Way ANOVA 
184 on Ranks, $\mathrm{H}=83.4, \mathrm{P}<0.001)$ and mass $(\mathrm{H}=79.3, \mathrm{P}<0.001)$ between populations 185 when females and males were pooled: the Ucayali population differed from all the 186 others in both mean length $(\mathrm{Q}=8.6, \mathrm{P}<0.05$ with the Putumayo, $\mathrm{Q}=6.7, \mathrm{P}<0.05$

187 with the Amazonas and $\mathrm{Q}=4.8, \mathrm{P}<0.05$ with the Napo $)$ and mass $(\mathrm{Q}=8.3, \mathrm{P}<0.05$

188 with the Putumayo, $\mathrm{Q}=6.8, \mathrm{P}<0.05$ with the Amazonas and $\mathrm{Q}=4.5, \mathrm{P}<0.05$ with 189 the Napo), whereas the other populations did not differ between each other in mean 190 length nor in mean mass. Maximum lengths and even more masses, however, did 191 vary considerably between populations, reaching barely $80 \mathrm{~cm}$ and about $3.8 \mathrm{~kg}$ in 192 the Putumayo and more than $90 \mathrm{~cm}$ and $8 \mathrm{~kg}$ in the Amazonas (Figure 2a). In the 193 Amazonas, maximum observed body mass for the silver Arowana was 49, 75 and $194113 \%$ heavier than in the Napo, Ucayali and Putumayo, respectively. These 195 important differences in body mass, however, are not a mere reflection of the larger 196 maximum lengths in the Amazonas. Indeed, although mass-at-length is relatively 197 similar between populations until about $50 \mathrm{~cm}(\sim$ size at first sexual maturity, see 198 below), afterwards fish start to become progressively heavier at a given length in the 199 Amazonas than in the Ucayali, Napo and Putumayo, in order of increasing difference 200 (Fig. 2b). These differences reached $\sim 500 \mathrm{~g}$ and $\sim 1000 \mathrm{~g}$ at 70 and $80 \mathrm{~cm}$, 201 respectively, between the Amazonas and Putumayo sub-basins (Fig. 2b).

202 For comparison purposes with other studies, a relationship between standard length 203 (SL) and total length (TL) is provided, calculated from all individuals in Figure 2a, 204 giving: $\mathrm{SL}=0.9345 \mathrm{TL}+0.102$. 
208 Females and males silver Arowana only have one functional gonad, the left one. The

209 right gonad is atrophied. An illustrated, detailed gonadal maturity scale is presented

210 in Figure 3 for both females and males. It allows for a clear determination of the

211 breeding season, size / age at maturity and fecundity.

212 The precise description of the gonadal cycle also allowed identifying that the silver

213 Arowana is a multiple-spawner (sensu Nuñez and Duponchelle 2009). Indeed, the

214 presence of small, vetelogenic oocytes in between large oocytes in "spawning

215 capable" ovaries, both in stage 3 or 4 (Figure 4a) and in stage 5-2 (recently spawned)

216 ovary initiating another vitellogenic cycle (Figure 4b), observed in all four sub-

217 basins, proves that a same female can reproduce at least twice during a breeding

218 season. Further evidences come from the size frequency distribution of oocytes in

219 "spawning capable" ovaries from the Putumayo sub-basin, showing two clearly

220 separated modes of vitellogenic oocytes: the largest (of 244 oocytes) that will be

221 spawned shortly and a smaller one (of 221 oocytes) that will likely be released in

222 another spawning bout during the same breeding season (Fig. 5).

224 Breeding season

226 There exists a relationship, albeit not a direct one, between the reproductive cycle of

227 the silver Arowana (estimated from the monthly proportions of females in "spawning 228 capable" phase of the gonadal maturation scale) and the hydrological cycle (Figure

229 6). In the Amazonas and Ucayali rivers, which have comparable hydrological cycles,

230 females have similar breeding seasons. Although sampling could not be completed at

231 some months, it can nevertheless be observed that the breeding season started during

232 the dry season (August-September) and ended before the water level reaches its 
233 maximum in both rivers. Some residual reproductive activity could be observed in

234 the Ucayali at almost every month outside the main breeding season. Again, in the

235 Napo and Putumayo rivers, which have comparable hydrological periodicity, the

236 breeding season of the silver Arowana also tended to be similar (Figure 6). Although

237 sampled could not be obtained in December and January in the Putumayo, it is likely

238 that, as in the Napo, the breeding season initiated in December to peak in February-

239 March. The breeding season in the Napo and Putumayo, however, did not last as

240 long as in the Amazonas and Ucayali and was restricted to the low water period.

242 Size and age at sexual maturity

244 Females tended to have slightly larger size at first sexual maturity (Figure 7) than

245 males in every sub-basin, but these differences were not significant ( $\mathrm{t}$-test, $\mathrm{t}=0.292$,

$246 \mathrm{df}=24, \mathrm{p}=0.773$ for the Amazonas; $\mathrm{t}=0.226, \mathrm{df}=24, \mathrm{p}=0.823$ for the Ucayali; $\mathrm{t}=0.630$,

$247 \mathrm{df}=18, \mathrm{p}=0.536$ for the Napo; and $\mathrm{t}=0.327, \mathrm{df}=24, \mathrm{p}=0.746$ for the Putumayo).

248 The size at maturity did not differ significantly between sub-basins for females nor 249 males.

250 Age at first sexual maturity was reached during the second year for both males and

251 females in all four sub-basins (Figure 7).

252 In all four sub-basins, the size at which $100 \%$ of both males and females were

253 sexually mature was slightly before $60 \mathrm{~cm} \mathrm{~S}_{\mathrm{L}}$ (Figure 7).

255 Fecundity 
257 The number of oocytes per spawning event (batch fecundity) significantly varied 258 (ANCOVA, $\mathrm{D}_{3,41}=6.610, \mathrm{P}<0.001$ ) between fish of the four sub-basins (Figure 8,

259 Table 1). Batch fecundity ranged from 93 to 256 oocytes for females of 1300 and $2604960 \mathrm{~g}$, respectively in the Amazonas, from 94 to 311 oocytes for females of 2080 261 and $3480 \mathrm{~g}$, respectively in the Ucayali, from 92 to 197 oocytes for females of 1460 262 and $3220 \mathrm{~g}$, respectively in the Napo and from 125 to 360 oocytes for females of 2631770 and 2980 g, respectively in the Putumayo.

264 The Putumayo population differed significantly from the Amazonas (ANCOVA, $\left.265 \mathrm{D}_{1,32}=25.9, \mathrm{P}<0.0001\right)$, Napo $\left(\mathrm{D}_{1,30}=9.7, \mathrm{P}<0.05\right.$ with Napo $)$ and Ucayali $\left(\mathrm{D}_{1,33}=\right.$ $26653.9, \mathrm{P}<0.001$ ) populations, whereas the Amazonas, Ucayali and Napo populations 267 did not significantly differ between each other $\left(\mathrm{D}_{2,12}=1.4, \mathrm{P}>0.05\right)$.

268 Relative fecundity (batch fecundity per unit body mass), oocyte diameter and oocyte 269 mass are presented in Table 2. Relative fecundity differed significantly between fish 270 of the four sub-basins (One-way ANOVA, F3 = 11.6, $\mathrm{P}<0.001$ ). Holm-Sidak post271 hoc test indicated that fish from the Putumayo significantly differed from the 272 Amazonas $(\mathrm{t}=4.812, \mathrm{P}<0.001)$, the Ucayali $(\mathrm{t}=3.614, \mathrm{P}=.0 .004)$ and the Napo $(\mathrm{t}$ $273=2.732, \mathrm{P}=0.037)$, whereas fish from the Amazonas, Ucayali and Napo did not 274 differ significantly between each other.

275 There was no significant difference in mean oocytes diameter or mass between fish 276 of the four sub-basins (Table 2).

\section{Discussion}

280 Important length and even more important body mass differences were observed 281 between the four sub-basins, as already pointed out while studying age and growth 
282 patterns of these same populations (Duponchelle et al., 2012). After reaching sexual

283 maturity, fishes in the Amazonas become progressively heavier than those from the

284 Ucayali, Napo and Putumayo, in order of increasing difference. Beside inter-basin

285 differences, silver Arowana from the Peruvian Amazon grow relatively heavier than

286 fish from the Mamirauá Reserve in Brazil. An individual of $80 \mathrm{~cm} \mathrm{~T}_{\mathrm{L}}\left(\sim 75 \mathrm{~cm} \mathrm{~S} \mathrm{~S}_{\mathrm{L}}\right)$

287 weighs $\sim 3000 \mathrm{~g}$ in the Mamirauá Reserve (Cavalcante, 2008), whereas it weighs in

288 average $3161 \mathrm{~g}$ in the Putumayo, $3369 \mathrm{~g}$ in the Napo, $3552 \mathrm{~g}$ in the Ucayali and 3702

$289 \mathrm{~g}$ in the Amazonas. The better body condition of Arowana in the Peruvian Amazon

290 might result from better trophic conditions than in the Mamirauá Reserve, which

291 would have to be tested.

293 Gonadal maturity scale

295 The description of the different maturity stages were consistent with Aragao' (1989)

296 descriptions, for both females and males, although the number of stages was reduced

297 to fit Nuñez and Duponchelle' (2009) scale. This illustrated gonadal maturity scale

298 provides a clear reference for comparative works on the reproductive biology of this

299 species.

300 Previous studies had suggested, from the observation of different sizes of oocytes in

301 ripe gonads (but without providing evidence) that a same female could reproduce

302 more than once during the breeding season (Ayala, 2001; Tang and Gomez, 2005). In

303 the present study, the presence of small, vitellogenic oocytes in all stages of

304 "spawning capable" ovaries and the size frequency distribution of oocyte in

305 "spawning capable" ovaries provide strong evidence that a same individual female

306 can reproduce more than once during the breeding season in the Peruvian Amazon. 
307 This result, however, differs from other studies in the Brazilian Amazon, Aragao

308 (1989) in Lake Janavaca and more recently Queiroz (2008) in the Mamirauá

309 Reserve, who reported that this species probably spawns only once during the

310 breeding season, but without providing demonstrating evidence.

\section{Breeding season}

314 In Central Amazonia, Brasil, where most published studies about the silver

315 Arowana's breeding cycle were carried out, the species was reported to reproduce

316 during the dry season and early rising waters (Goulding, 1980; Aragao, 1989;

317 Queiroz, 2008; Cavalcante, 2008). This is consistent with the observations from the 318 present study in the Amazonas and Ucayali sub-basins, or with previous observations

319 in Peru, in the Pacaya Samiria Reserve (Tang and Gomez, 2005) and in the Ucayali

320 River (Ayala, 2001). This pattern, however, does not seem to hold for all silver

321 Arowana of the Peruvian Amazon, as the breeding season seemed restricted to the

322 dry season in the Napo and Putumayo sub-basins. This shorter breeding season might

323 be an adaptation to the much shorter flooding season in the Napo and Putumayo

324 (Figure 5). Once females have spawned, males guard the eggs and then the fry in

325 their mouth for five to seven weeks (Goulding, 1990; Argumedo, 2005; Queiroz,

326 2008), after which free swimming juveniles of over $6 \mathrm{~cm}$ are released from parental

327 care and have to fend for themselves. It is well known that in Amazonian

328 environments, the high water season with its extended floodplains and inundated

329 vegetation, providing food and shelter from predators is particularly advantageous

330 for the development and survival of fish's young stages (Lowe-McConnell, 1964, 331 1987; Goulding, 1980). In order for males to release their free-swimming young in 
332 time to make the most of these advantageous environmental conditions - which

333 barely last three months in the Napo and Putumayo sub-basins (Figure 5) -, while

334 allowing for the long incubation, the spawning period might have to be finished

335 when the water starts to rise. Nevertheless, size frequency distribution of oocytes in

336 ripe gonads (Figure 4c) and the presence of small vitellogenic oocytes in all stages of

337 "spawning capable" ovaries support the idea that individual females may have time

338 to produce a second brood during the spawning period, despite its shorter duration in

339 the Putumayo. This suggests that the time needed for the small vitellogenic oocytes

340 (Fig. 4a-b) to complete their growth is relatively short (a few weeks). These results

341 also imply polyandry in the species: indeed, the short breeding season in the

342 Putumayo and Napo and the long paternal mouthbrooding period do not allow for a

343 same male to carry successively two broods of a same female. On the other hand, in

344 the Amazonas and Ucayali sub-basins, where the high water season lasts nearly

345 twice as much (December to May), females that spawn when the water has already

346 started to rise may still ensure their progeny will find favourable environmental

347 conditions long enough to survive, hence ensure reproductive success. This

348 hypothesis could be tested by additional studies on these two specific sub-basins and

349 others with similarly short high water seasons. As Arowana do not live in rivers, but

350 instead in adjacent lakes and lagoons, testing this hypothesis would also require

351 having water level data in specific lakes where Arowana concentrations are high.

353 Age and size at maturity

355 In the Mamirauá Reserve, the size at first sexual maturity was about $52 \mathrm{~cm} T_{L}(\sim 49$

$356 \mathrm{~cm} \mathrm{~S}_{\mathrm{L}}$ ) for both sexes and was reached during the second year (Cavalcante, 2008). 
357 These values were relatively similar to those observed in the Peruvian Amazon,

358 where silver Arowana also reached maturity during their second year at sizes varying

359 between $43-45 \mathrm{~cm}$ for males and between $46-50 \mathrm{~cm}$ for females. These values were

360 relatively smaller than the $\sim 60 \mathrm{~cm} \mathrm{~T}_{\mathrm{L}}(\sim 56 \mathrm{~cm} \mathrm{~S} \mathrm{~L})$ reported in the El Dorado lake in

361 the Pacaya Samiria Reserve, Peru (Tang and Gomez, 2005). In a preliminary study in

362 the Ucayali River, Peru, Ayala (2001) reported sizes at first maturity of 65.9 and 73.9

$363 \mathrm{~cm} \mathrm{~T}_{\mathrm{L}}\left(\sim 62\right.$ and $\left.69 \mathrm{~cm} \mathrm{~S}_{\mathrm{L}}\right)$ for females and males, respectively. These obviously

364 over-estimated values, however, were likely due to the fact that the author

365 erroneously considered individuals in vitellogenesis (stage II of his gonadal

366 maturation scale) as still immature. Cortegano et al. (2014) reported sizes at maturity

367 of $\sim 58$ and $62 \mathrm{~cm}$ for females and males, respectively in lake Grande, close to

368 Huapapa in the Putumayo. These large differences with our results from the

369 Putumayo (47 and $43 \mathrm{~cm}$ for females and males, respectively) are particularly

370 surprising, as about a third of our own sampling also came from lake Grande. Most

371 of the observed differences might result from the interpretation of what is considered

372 as "sexual maturity" in Cortegano et al.' study, which was not properly defined. It is

373 likely, when looking at their logistic curves that reach $100 \%$ only close to the

374 maximum observed sizes, that they considered as "sexually mature" female at the

375 end of stage 2 rather than at the beginning of stage 2 (Fig. 3a). Likewise, for males,

376 they likely considered males in late stage 2 or stage 3 rather than in stage 2 (Fig. $3 b$ ).

378 It is worth noting that while the other reproductive traits (breeding season and

379 fecundity) largely varied between sub-basins, size at maturity was relatively

380 conserved and that the slight differences observed were not significant. This is

381 particularly surprising as size at maturity is a plastic trait that readily responds to

382 environmental variation (Stearns and Crandall, 1984; Stearns and Koella, 1986; 
383 Duponchelle and Panfili, 1998; Duponchelle et al., 2007) or fishing pressure (Olsen

384 et al., 2004). This observation will have to be confirmed on other geographic

385 populations.

386 It is important to keep in mind that the size at first sexual maturity $\left(\mathrm{L}_{\mathrm{m}}\right)$ is the size at

387 which $50 \%$ of the individuals have reached maturity during the breeding season,

388 which means the other $50 \%$ have not. Considering the size at first sexual maturity as

389 the legal minimum size at capture, as is customary in Amazonian fisheries

390 regulations, we implicitly allow that half the fish be caught as immature, hence

391 before they could reproduce (growth-overfishing). In order to ensure a healthy

392 spawning stock, however, fisheries should ensure that all captured individuals have

393 had a chance to reproduce at least once (Myers and Mertz, 1998; Froese, 2004). This

394 goal can only be attained by fixing the minimum size at capture not at the size at

395 which $50 \%$ of the individuals in a population are mature $\left(\mathrm{L}_{\mathrm{m}}\right)$, but at the size at

396 which $100 \%$ are mature. The size at which $100 \%$ of the fish are mature, considering

397 all four sub-basins of the Peruvian Amazon, was slightly below $60 \mathrm{~cm} \mathrm{~S} \mathrm{~L}_{\mathrm{L}}$ (Fig. 6).

398 Therefore, considering the approximately $5 \mathrm{~cm}$ difference between total and standard

399 lengths, we recommend that the minimum size at capture should be fixed at $60 \mathrm{~cm}$

$400 \mathrm{~T}_{\mathrm{L}}$ in the Peruvian Amazon.

401

402 Fecundity

403

404 The silver Arowana reputedly produces very few eggs for its size (Goulding, 1980;

405 Aragao, 1989; Queiroz, 2008). Fecundity variations between geographical samples,

406 however, have never been reported so far. In the present study, important differences

407 in batch fecundity were observed between the silver Arowana of the four sub-basins. 
408 The Putumayo population significantly differed from the other three populations,

409 which in turn did not differed between each other's. The absence of significant

410 difference between the Amazonas, Napo and Ucayali populations, however, was

411 likely due to the low number of gonads analysed and to the large variance observed

412 in the Ucayali population (Fig. 7). Such a large variance could result from the mixing

413 of individuals from distinct populations within the Ucayali sub-basin. Indeed, fish

414 were sampled from fishermen operating in large portions of the Ucayali basin and

415 which could hold populations with distinct reproductive characteristics. This

416 indicates that further studies on this species will need to be carried out with on-site

417 sampling rather than market sampling. Nevertheless, as an illustration of the

418 important fecundity variation between fish of the four sub-basins, despite the absence

419 of statistical significance, the batch fecundity at two representative female body

420 masses (1500 and $3500 \mathrm{~g}$ ) was calculated for each sub-basin from the regressions

421 among batch fecundity and body mass (Table 1). The differences of batch fecundity

422 between populations ranged from 33 to $104 \%$ for females weighing 1500 and 3500

$423 \mathrm{~g}$, respectively. Given the energetic cost of gamete production, food is considered

424 one of the most important environmental factors involved in the regulation of

425 fecundity (Wooton, 1979; Wooton, 1998). One would thus expect the fish with the

426 better body condition (in decreasing order those of the Amazonas, then Ucayali,

427 Napo and Putumayo, see Fig. 2b), which usually reflects better trophic conditions, to

428 also display the highest relative fecundity. Yet, relative fecundity was inversely

429 proportional to body condition (Table 2), suggesting contrasted energy allocation

430 (towards body growth $v s$ reproduction) strategies between fish of the four sub-basins.

431 Additionally, these large variations in fecundity were not compensated by variations

432 of oocyte size or mass, suggesting differences in reproductive effort between fish of 
433 the four the sub-basins. These hypotheses, however, will need to be further validated

434 with an increased number of ripe gonads analysed in the Amazonas, Napo and

435 Ucayali sub-basins.

436 As a comparison, in the Mamirauá Reserve females of $65 \mathrm{~cm} \mathrm{~T}_{\mathrm{L}}\left(\sim 61 \mathrm{~cm} \mathrm{~S}_{\mathrm{L}}\right.$ and

$437 \quad 1500 \mathrm{~g})$ and $75 \mathrm{~cm} \mathrm{~T}_{\mathrm{L}}\left(\sim 70 \mathrm{~cm} \mathrm{~S} \mathrm{~S}_{\mathrm{L}}\right.$ and $\left.2500 \mathrm{~g}\right)$ produce $\sim 200$ and 230 oocytes,

438 respectively (Queiroz, 2008, using the length-mass relationship provided in

439 Cavalcante, 2008). This would be approximately twice as much as the fecundity of a

$4401500 \mathrm{~g}$ female in the Peruvian Amazon and in the range of the Putumayo fecundity

441 for a $2500 \mathrm{~g}$ female (Table 1), suggesting a higher relative fecundity in small females

442 progressively decreasing with length in the Mamirauá Reserve. Again, fish from the

443 Mamirauá, which have lower body condition than fish from the Peruvian Amazon,

444 also have higher relative fecundity, contrary to expectations. A surprising

445 information comes from the mean diameter $(9.75 \mathrm{~mm})$ and mass $(1.8 \mathrm{~g})$ of oocytes in

446 the Mamirauá Reserve, which are 25\% smaller but a 100\% heavier than the largest

447 and heaviest oocytes in the Peruvian Amazon (12.2 $\mathrm{mm}$ and $0.98 \mathrm{~g}$ in the Putumayo),

448 resulting in a density over $3.5 \mathrm{~g} / \mathrm{cm}^{3},\left(v s 1.03 \mathrm{~g} / \mathrm{cm}^{3}\right.$ in the Putumayo), which appears

449 much too dense for an egg.

450 In the Pacaya-Samiria Reserve, Peru, Tang and Gomez (2005) observed that females

451 of 1500 and $2500 \mathrm{~g}$ would produce in average 215 and 266 oocytes, respectively,

452 which is above the mean values observed in the present study. A recent study in lake

453 Grande on the Putumayo River, reported batch fecundities ranging from 115 oocytes

454 for a female weighing $1100 \mathrm{~g}$ to $\sim 240$ oocytes for a female of $\sim 3000 \mathrm{~g}$ (Cartegano et

455 al., 2014), within the range of the values observed for the Putumayo in the present

456 study. 
457 The only other available information about the silver Arowana's fecundity comes 458 from Aragao (1989) in the Solimões River basin (lake Janauacá), but the range of

459 female body masses he worked with $(551-1750 \mathrm{~g}$, with only 2 females above 1500

460 g) barely overlap with ours, hampering a direct comparison. Nevertheless, a $1500 \mathrm{~g}$

461 female would produce approximately 182 oocytes, which is also above the mean

462 values observed in the present study.

464 Conclusions

465 The important variability observed in reproductive characteristics and body condition

466 of the silver Arowana from the four sub-basins is consistent with the important

467 growth variations previously reported in these same localities (Duponchelle et al.,

468 2012). This variability might result either from the phenotypic plasticity of the

469 species due to environmental heterogeneity between the sub-basins or from the

470 existence of several distinct genetic populations within Peru, that may need to be

471 further characterized and managed independently. The important differences in

472 breeding season, condition, growth and fecundity, however, strongly suggest that fish

473 from the different sub-basins are distinct populations. The different breeding season

474 and sedentary nature of the species should result in reduced gene flow between sub-

475 basins, hence inducing genetic structuring. Although microsatellites markers are

476 available for the silver Arowana (Silva et al., 2009), they have only been used to test

477 for multiple paternity in the species (Verba et al., 2014) and no population genetic

478 study has been carried out so far. Yet, as previously pointed out (Duponchelle et al.,

479 2012), the growing concerns about $O$. bicirrhosum conservation (Moreau and

480 Coomes, 2006, 2007) emphasize the need for comparative life history and genetics

481 studies at the inter- and intra-basin levels (with sampling carried out on-site) in order 
482 to understand the population structuring of this species and to define appropriate

483 management strategies.

\section{Acknowledgements}

486 Financial support was provided by INCAGRO (Subproyecto "Bases para el manejo

487 sostenible y el cultivo de la arowana Osteoglossum bicirrhosum en la amazonía

488 peruana”, presentado al Concurso Público Nacional No 03-2007 - PIEA -

489 INCAGRO) and IRD. Special thanks go to the Proyecto Especial Desarrollo Integral

490 de la Cuenca del Río Putumayo (PEDICP), particularly to Luis Alberto Moya Ibanez,

491 for ensuring the sampling in the Putumayo. We would also like to thank Etienne

492 Baras for discussions on some aspect on the manuscript and Jérémie Subrini for

493 producing the size frequency distribution of oocytes.

\section{References}

497 Alcántara, B. F.; Chu-Koo, F.; Chávez, V. C. A.; Tello, S.; Bances, C. K. C.; Torrejón, M. M.; Gómez, N. J. L. ; Noriega, M. J., 2007: Notas sobre la pesquería ornamental de la arahuana Osteoglossum bicirrhosum (Osteoglossidae) en Loreto, Perú y

501 Aragao, L. P., 1989: Contribuição ao estudo da biologia do Aruanã, Osteoglossum bicirrhosum Vandelli, 1829, no Lago Janauacá - Estado do Amazonas, Brasil. IIIReprodução e relações biometricas. Cienc. Agronom. 20, 59-72. ACUICA, Fondo para la Accion Ambiental, Florencia, Colombia.

Ayala, I., 2001: Ecologia reproductiva de Ostoglossum bicirrhossum Vandelli, 1829 
"arahuana" en la cuenca del rio Ucayali, Ciencias en Conservacion de Recursos Forestales. MSc. Thesis, Universidad Nacional Agraria La Molina, Lima.

Barbieri, L. R.; Chittenden, J. M. E. ; Lowerre-Barbieri, S. K., 1994: Maturity, spawning, and ovarian cycle of Atlantic croaker, Micropogonias undulatus, in the Chesapeake Bay and adjacent coastal waters. Fish. Bull. 92, 671-685.

512 Bayley, P. B. ; Petrere, M., 1989: Amazon Fisheries: Assessment methods, current status and management options. in: Proceedings of the International Large River Aquatic Sciences, pp. 385-398.

Brown-Peterson, N. J.; Wyanski, D. M.; Saborido-Rey, F.; Macewicz, B. J. ; LowerreBarbieri, S. K., 2011: A standardized terminology for describing reproductive development in fishes. Mar. Coast. Fish. 3, 52-70.

Lima, A. C. ; Prang, G., 2008: Demandas para o manejo e conservação do Aruanã branco, Osteoglossum bicirrhosum (Cuvier, 1829), na região do Medio Solimões. in: Biologia, Conservação e Manejo dos Aruanãs na Amazônia Brasileira. H. L. Queiroz, M. Camargo (Eds.). Instituto de Desemvolvimento Sustentavel de Mamirauá, Téfé, Brasil, pp. 15-26.

Cavalcante, D., 2008: Crescimento e maturação sexual de Aruanãs brancos (Ostoglossum bicirrhosum) em Mamirauá. in: Biologia, Conservação e Manejo dos Aruanãs na Amazônia Brasileira. H. L. Queiroz, M. Camargo (Eds.). Instituto de Desemvolvimento Sustentavel de Mamirauá, Téfé, Brasil, pp. 105-117.

Cortegano, C. A. A.; Pinedo, L. A. M.; Ibanez, L. A. M.; Vásquez, M. R. ; Ruiz, P. S., 2014: Productivity and reproductive characteristics of silver arowana Osteoglossum bicirrhosum (Osteoglossiformes: Osteoglossidae) at Grande lake, Putumayo basin, Peru. Biota Amaz. 4, 21-26. 
532 Silva, T. J.; Hrbek, T. ; Farias, I. P., 2009: Microsatellite markers for the silver arowana 9, 1019-1022.

Duponchelle, F. ; Panfili, J., 1998: Variations in age and size at maturity of female Nile tilapia, Oreochromis niloticus, populations from man-made lakes of Côte d'Ivoire. Environ. Biol. Fish. 52, 453-465.

Duponchelle, F.; Lino, F.; Hubert, N.; Panfili, J.; Renno, J.-F.; Baras, E.; Torrico, J.P.; Dugué, R. ; Nuñez, J., 2007 Environment-related life history trait variations of the red-bellied piranha, Pygocentrus nattereri, in two river basins of the Bolivian Amazon. J. Fish Biol. 71, 1113-1134.

Duponchelle, F.; Ruiz Arce, A.; Waty, A.; Panfili, J.; Renno, J.-F.; Farfan, F.; GarciaVasquez, A.; Chu-Koo, F.; Garcia-Davila, C.; Vargas, G.; Ortiz, A.; Pinedo, R. ; Nuñez, J., 2012: Contrasted hydrological systems of the Peruvian Amazon induce differences in growth patterns of the silver arowana, Osteoglossum bicirrhosum. Aquat. Living Resour. 25, 55-66.

Froese, R., 2004: Keep it simple: three indicators to deal with overfishing. Fish. Fisher. 5, 86-91.

Garcia-Vasquez, A.; Tello, S.; Vargas, G. ; Duponchelle, F., 2009: Patterns of commercial fish landings in the Loreto region (Peruvian Amazon) between 1984 and 2006. Fish Physiol. Biochem. 35, 53-67.

554 Goulding, M., 1990: Amazon: The Flooded Forest. Sterling Publishing,, New York, USA. 555 Legendre, M. ; Ecoutin, J-M., 1989: Suitability of brackish water tilapia species from the 556 Ivory Coast for lagoon aquaculture 1 - Reproduction. Aquat. Living Resour. 2, 71- 
558 Lowe-McConnell, R. H., 1964: The fishes of the Rupununi savanna district of Bristish Guiana, South America. Part 1. Ecological groupings of fish species and effects of the seasonal cycle on the fish. J. Linn. Soc. (Zool.). 45, 103-144.

561 Lowe-McConnell, R. H., 1987: Ecological studies in tropical fish communities. Cambridge 562 University Press, Cambridge.

563 Mojica, J. I.; Castellanos, C.; Usma, J. S. ; Álvarez, R., 2002: Libro rojo de peces dulceacuícolas de Colombia. Instituto de Ciências Naturales - Universidad Nacional de Colômbia y Ministério del Médio Ambiente, Bogotá, Colômbia.

566 Moreau, M.-A. ; Coomes, O. T., 2006: Potential threat of the international aquarium fish 567 trade to silver arawana Osteoglossum bicirrhosum in the Peruvian Amazon. Oryx. 40, 152-160.

Moreau, M.-A. ; Coomes, O. T., 2007: Aquarium fish exploitation in western Amazonia: conservation issues in Peru. Environ. Conserv. 34, 12-22.

571 Myers, R. A. ; Mertz, G., 1998: The Limits of Exploitation: A Precautionary Approach. $572 \quad$ Ecol. Appl. 8, S165-S169.

573 Nuñez, J. ; Duponchelle, F., 2009: Towards a universal scale to assess sexual maturation and related life history traits in oviparous teleost fishes. Fish Physiol. Biochem. 35, 167180.

576 Olsen, E. M.; Heino, M.; Lilly, G. R.; Joanne Morgan, M.; Brattey, J.; Ernande, B.; Dieckmann, U., 2004: Maturation trends indicative of rapid evolution preceded the

579 Prang, G., 2008: An industry analysis of the freshwater ornamental fishery with particular reference to the supply of Brazilian freshwater ornamentals to the UK market. Uakari. 3, 7-51. 
582 Queiroz, H. L., 2008: Investimento parental e reprodução do Aruanã branco, Osteoglossum bicirrhosum, na Reserva Mamirauá. in: Biologia, Conservação e Manejo dos Aruanãs na Amazônia Brasileira. H. L. Queiroz, M. Camargo (Eds.).Instituto de Desemvolvimento Sustentavel de Mamirauá, Téfé, Brasil, pp. 119-132.

Reis, R. E.; Kullander, S. O. ; Ferraris, C. J., 2003: Checklist of freshwater fishes of South and Central America. Edipucrs, Porto Alegre.

Saint-Paul, U.; Zuanon, J.; Villacorta Correa, M.A.; Garcia, M.; Noemi Fabre, N.; Berger, U. ; Junk, W.J., 2000: Fish communities in central white- and blackwater floodplains. Environ. Biol. Fish. 57, 235-250.

591 Stearns, S. C.; Crandall, R. E., 1984: Plasticity for age and size at sexual maturity: a life history response to unavoidable stress. in: Fish Reproduction : strategies and tactics.

594 Stearns, S. C.; Koella, J. C., 1986: The evolution of phenotypic plasticity in life history traits: predictions of reaction norms for age and size at maturity. Evolution 40, 893-

597 Stewart, D. J., 2013b: A new species of Arapaima (Osteoglossomorpha, Osteoglossidae) from the Solimões River, Amazonas State, Brazil. Copeia 3, 470-476.

599 Stewart, D. J., 2013a: Re-description of Arapaima agassizii (Valenciennes), a rare fish from Brazil (Osteoglossomorpha, Osteoglossidae). Copeia 1, 38-51.

601 Tang, M. ; Gomez Noriega, J. L., 2005: Biologia y aprovechamiento del Arahuana, Osteoglossum bicirrhosum en la micro cuenca de lacocha El Dorado, Reserva Nacional Pacaya Samiria, Facuiltad de Ciencias Biologiacas. Universidad Nacional de la Amazonia Peruana, Iquitos. 
607 Verba, J. T.; Rabello Neto, J. G.; Zuanon, J. ; Farias, I. P., 2014: Evidence of multiple paternity and cooperative parental care in the so called monogamous silver arowana Osteoglossum bicirrhosum (Osteoglossiformes: Osteoglossidae). Neotrop. Ichtyol. 12, $145-151$.

611 Wootton, R. J., 1979: Energy cost of egg production and environmental determinants of 612 fecundity in teleost fishes. Symp. Zool. Soc. Lond. 44, 133-159.

613 Wootton, R. J., 1998: The ecology of teleost fishes, Second Edition. Kluwer Academic 614 Publisher, Dordrecht, The Netherlands.

616 Author's address: Institut de Recherche pour le Développement (IRD), Unité Mixte de

617 Recherche Biologie des Organismes et Ecosystèmes Aquatiques (UMR BOREA - MNHN,

618 CNRS-7208, UPMC, UCBN, IRD-207), F-34394, Montpellier, France.

619 E-mail: fabrice.duponchelle@ird.fr, tel: (33) 0467636428

\section{$622 \quad$ Figure legends}

624 Fig. 1. Map of the collection sites of Osteoglossum bicirrhosum in the Peruvian 625 Amazon (black circles). A total of 711 specimens were collected between November 6262006 and April 2009 at the Iquitos and Requena markets for the Amazonas, Ucayali 627 and Napo sub-basins. For the Putumayo, 240 fish were bought between March 2008 628 and April 2009 from local fishermen at El Estrecho and Huapapa communities. 629

630 Fig. 2. Relationships between standard length (SL) and total body mass (M) of 631 Osteoglossum bicirrhosum caught in four sub-basins of the Peruvian Amazon 
632 between 2006 and 2009 (a). Modelled regressions (M as a function of SL) between

63360 and $90 \mathrm{~cm} \mathrm{SL}$, to illustrate inter-basin differences (b).

634

635 Fig. 3. Macroscopic gonadal maturity scale for females (a) and males (b)

636 Osteoglossum bicirrhosum, following Nuñez and Duponchelle (2009). Equivalence

637 with Brown-Petersen et al. (2011)'s terminology is provided.

638

639 Fig. 4. Small vitellogenic oocytes (svo) in "spawning capable" ovaries of female

640 Osteoglossum bicirrhosum: (a) in between large vitellogenic oocytes (lvo) in a ripe -

641 stage 4 - gonad and (b) in a post-spawning gonad reinitiating another vitellogenic

642 cycle - stage 5-2.

643

644 Fig. 5. Size frequency distribution of oocytes in a "spawning capable" ovary of

645 Osteoglossum bicirrhosum from the Putumayo River showing two clearly separated

646 modes of vitellogenic oocytes.

647

648 Fig. 6. Proportions of breeding Osteoglossum bicirrhosum females in relation to the

649 mean water level in four sub-basins of the Peruvian Amazon.

651 Fig. 7. Age (Am) and size (Lm) at first sexual maturity of both males (black circles

652 and solid lines) and females (white triangles and dashed lines) Osteoglossum

653 bicirrhosum in four sub-basins of the Peruvian Amazon.

654

655 Fig. 8. Linear regressions between batch fecundity and total female body mass of

656 Osteoglossum bicirrhosum in the Amazonas $\left(\mathrm{N}=5, \mathrm{~F}=0.0307 * \mathrm{M}+60.922, \mathrm{R}^{2}=\right.$ 
657 0.875, $\mathrm{P}<0.001)$, Napo $\left(\mathrm{N}=3, \mathrm{~F}=0.0578 * \mathrm{M}+18.547, \mathrm{R}^{2}=0.907, \mathrm{P}<0.001\right)$,

658 Ucayali $\left(\mathrm{N}=6, \mathrm{~F}=0.0708^{*} \mathrm{M}-9.1942, \mathrm{R}^{2}=0.537, \mathrm{P}<0.001\right)$ and Putumayo $(\mathrm{N}=28$,

$\left.659 \mathrm{~F}=0.1055^{*} \mathrm{M}-29.253, \mathrm{R}^{2}=0.714, \mathrm{P}<0.001\right)$ rivers, Peruvian Amazon.

660

661 Table 1. Comparison of Osteoglossum bicirrhosum's batch fecundity at a given

662 female body mass in four sub-basins of the Peruvian Amazon (calculated from the

663 regressions between batch fecundity and total body mass presented in Figure 8).

664

665 Table 2. Mean relative fecundity (oocytes per kg total body mass), oocytes diameter

$666(\mathrm{~mm})$ and oocytes mass $(\mathrm{g}) \pm \mathrm{SD}$ of Osteoglossum bicirrhosum in four sub-basins of

667 the Peruvian Amazon.

668 


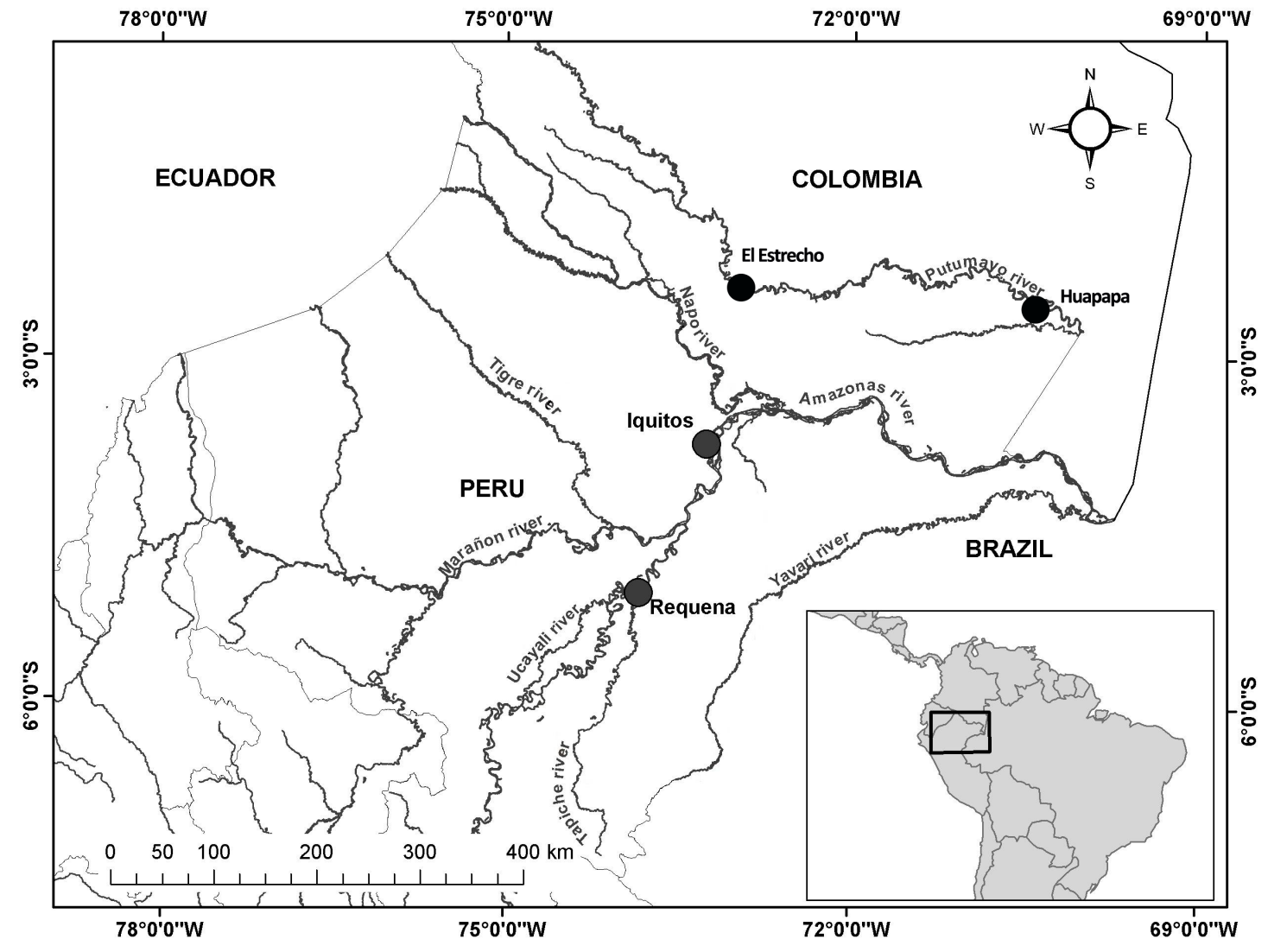

Fig. 1 

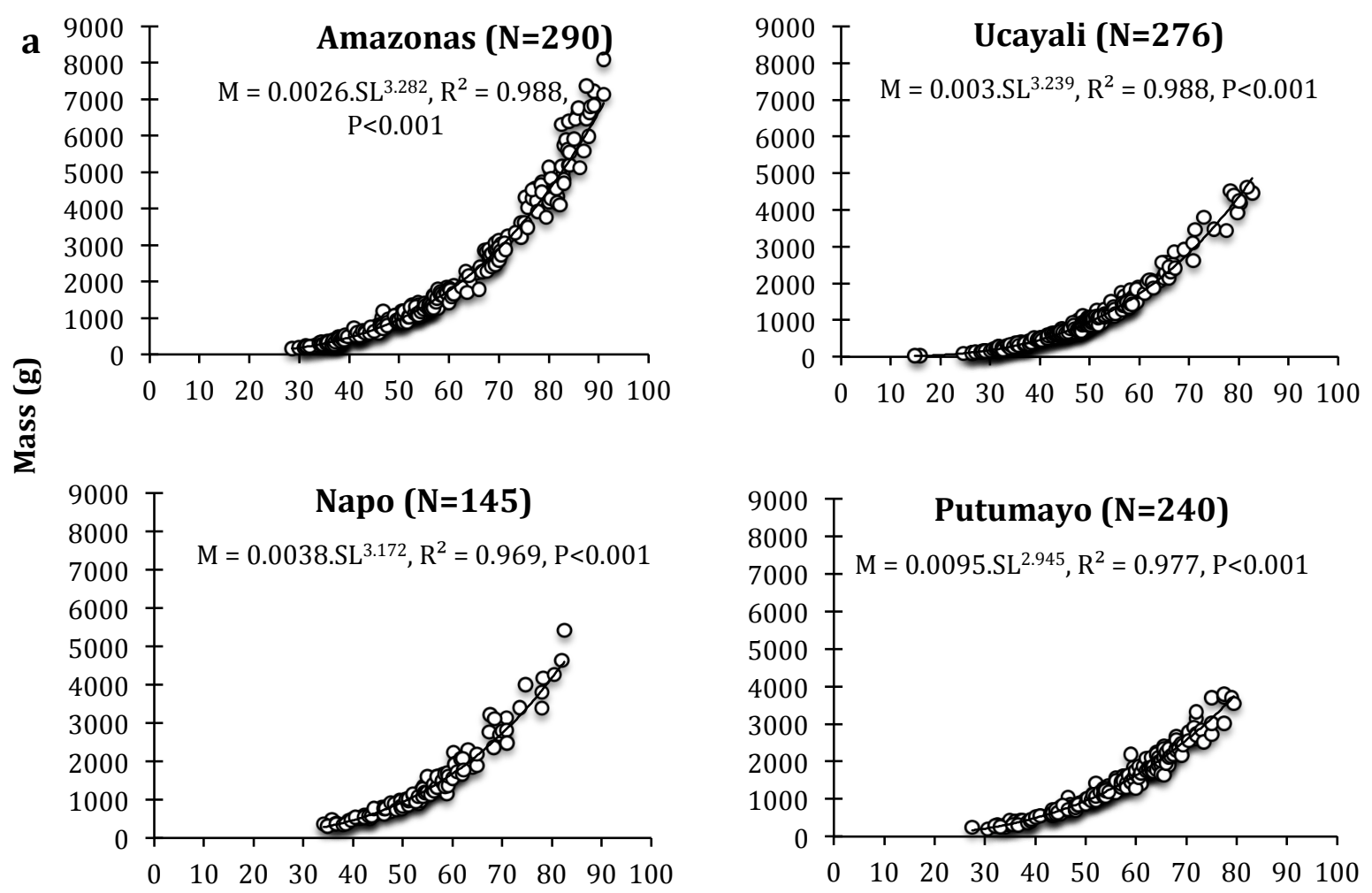

\section{Standard length (cm)}

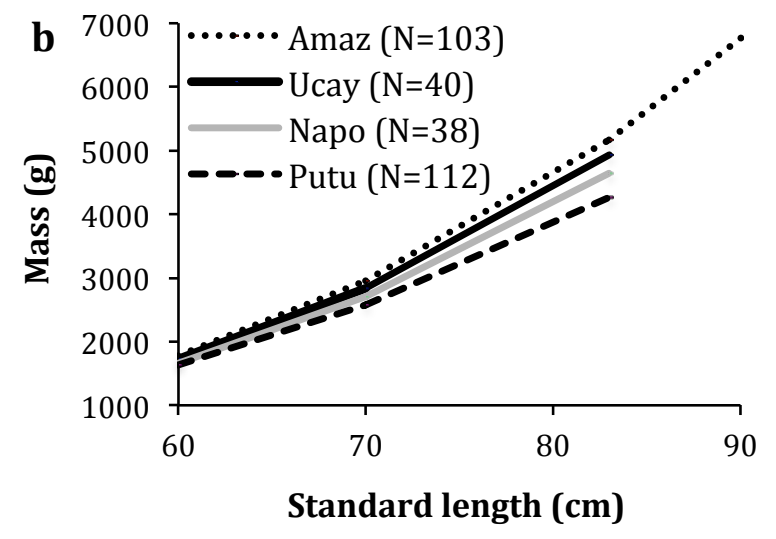

Fig. 2 


\begin{tabular}{|c|c|c|}
\hline Description & Illustration (females) & $\begin{array}{l}\text { with Brown- } \\
\text { Petersen et } \\
\text { al. (2011)'s } \\
\text { terminology }\end{array}$ \\
\hline $\begin{array}{l}\text { Stage 1: immature individuals } \\
\text { Ovaries small and firm, opaque and whitish or } \\
\text { slightly pinkish. No oocyte can be seen to the naked } \\
\text { eye. A typical longitudinal canyon-type depression is } \\
\text { clearly visible at the surface of the ovary. }\end{array}$ & & Immature \\
\hline $\begin{array}{l}\text { Stage 2: maturing individuals } \\
\text { Ovaries are larger with more important } \\
\text { vascularisation and clearly visible oocytes. Oocytes } \\
\text { are whitish and sparse at the beginning of stage } 2 \text {, } \\
\text { and the canyon-like depression is still visible. } \\
\text { Progressively, the oocytes turn yellow and the } \\
\text { canyon disappears. At the end of stage 2, the oocytes } \\
\text { are orange and fill the ovary, but are not of a } \\
\text { homogeneous size: all intermediaries between small } \\
\text { whitish oocytes and large orange ones are visible. } \\
\text { This last point is a clear distinction with stage } 3 \text {. }\end{array}$ & & Developing \\
\hline $\begin{array}{l}\text { Stage 3: individuals in final maturation } \\
\text { The ovary now occupies about } 3 / 4 \text { of the abdominal } \\
\text { cavity. Most oocytes are large, circular, orange, and } \\
\text { homogeneous in size. Small oocytes are still visible } \\
\text { in between the larger ones, but there is now a very } \\
\text { clear size difference between the large and small } \\
\text { ones. }\end{array}$ & & \\
\hline $\begin{array}{l}\text { Stage 4: individuals ready to spawn / ripe } \\
\text { The ovary occupies almost the whole abdominal } \\
\text { cavity and appears even fuller. The ovary's } \\
\text { membrane is very thin and transparent. A slight } \\
\text { pressure on the abdomen can expulse the ovules, that } \\
\text { are now free (out of their follicules) in the ovary. }\end{array}$ & & $\begin{array}{l}\text { Spawning } \\
\text { capable }\end{array}$ \\
\hline $\begin{array}{l}\text { Stage 5-2: recently spawned individuals initiating } \\
\text { another cycle } \\
\text { The appearance is close to that of a stage } 2 \text { gonad, } \\
\text { but the ovary is still relatively flaccid, larger and } \\
\text { more vascularised. Developing oocytes of all } \\
\text { colours are filling the ovary and some remaining } \\
\text { large atretic oocytes can sometimes be observed. } \\
\text { This stage is characteristic of females that have just } \\
\text { spawn and that are initiating a new reproductive } \\
\text { cycle. }\end{array}$ & & \\
\hline
\end{tabular}




\begin{tabular}{|l|l|l|}
\hline $\begin{array}{l}\text { Stage 5: individuals that have just spawned } \\
\text { The ovary is of similar size to a stage 4 ovary, but } \\
\text { with an empty, flaccid appearance and well } \\
\text { developed vascularisation. Some un-spawned, large } \\
\text { oocytes can still be seen together with others already } \\
\text { in re-absorption process (atresia) and early } \\
\text { vitellogenic ones. }\end{array}$ & Regressing \\
\hline $\begin{array}{l}\text { Stage 5-1: resting individuals } \\
\text { The ovary looks like a stage } 1 \text { ovary (with no visible } \\
\text { oocyte), but is larger, with a thicker membrane, a } \\
\text { more important vascularisation and a generally } \\
\text { redder colour than a stage 1. This stage is } \\
\text { characteristic of adult females resting in between two } \\
\text { breeding seasons. }\end{array}$ & Regenerating \\
\hline
\end{tabular}

Fig. 3a.

\begin{tabular}{|c|c|c|}
\hline Description & Illustration (males) & $\begin{array}{l}\text { Equivalence with } \\
\text { Brown-Petersen } \\
\text { et al. (2011)'s } \\
\text { terminology }\end{array}$ \\
\hline $\begin{array}{l}\text { Stage 1: immature individuals: } \\
\text { The testis is a pinkish, translucent curved tube, } \\
\text { thinner and longer than stage } 1 \text { ovary. It is often } \\
\text { bordered by a golden colour towards the genital } \\
\text { pore. }\end{array}$ & & Immature \\
\hline $\begin{array}{l}\text { Stage 2: maturing or resting individuals: } \\
\text { Testis wider, thicker, of a more opaque pinkish to } \\
\text { reddish colour. The golden colour towards the } \\
\text { genital pore is often still visible. } \\
\quad \text { Resting adults are usually at this stage. }\end{array}$ & & $\begin{array}{l}\text { Developing } \\
\text { Regenerating }\end{array}$ \\
\hline $\begin{array}{l}\text { Stage 3: ripe individuals: } \\
\text { Testis even larger, wider and really thick, with dark } \\
\text { red opaque appearance. The golden colour is } \\
\text { usually not visible at this stage. }\end{array}$ & & Spawning capable \\
\hline $\begin{array}{l}\text { Stage 4: individuals after ejaculation: } \\
\text { Testis of a similar size to stage } 3 \text {, but with a } \\
\text { flaccid, more translucent appearance. }\end{array}$ & & Regressing \\
\hline
\end{tabular}

Fig. 3b. 


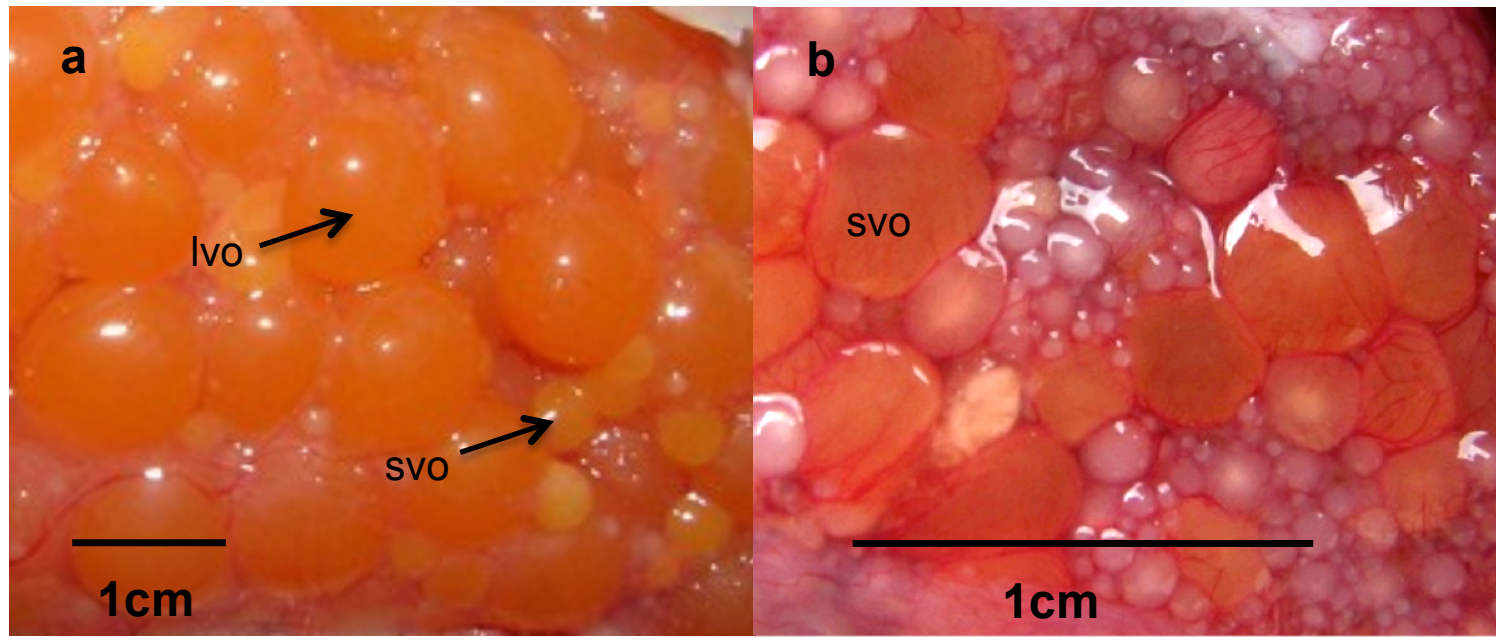

Fig. 4 


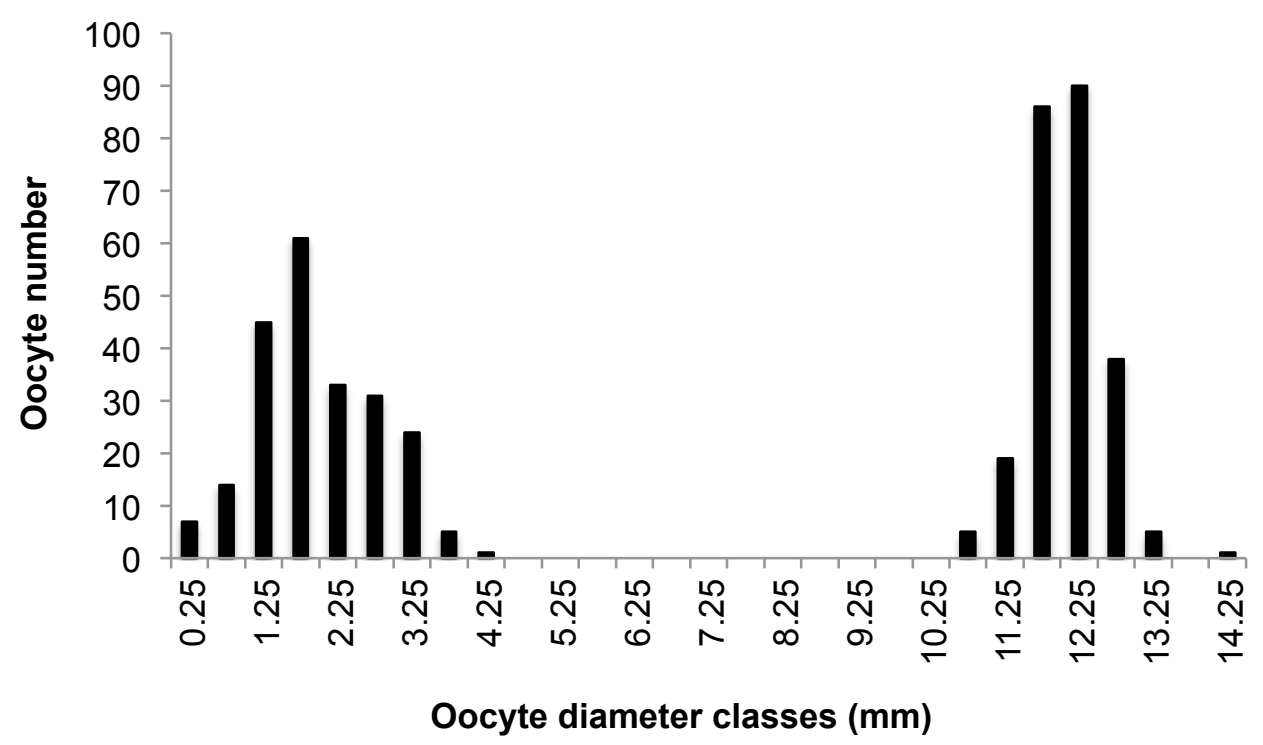

Fig. 5 

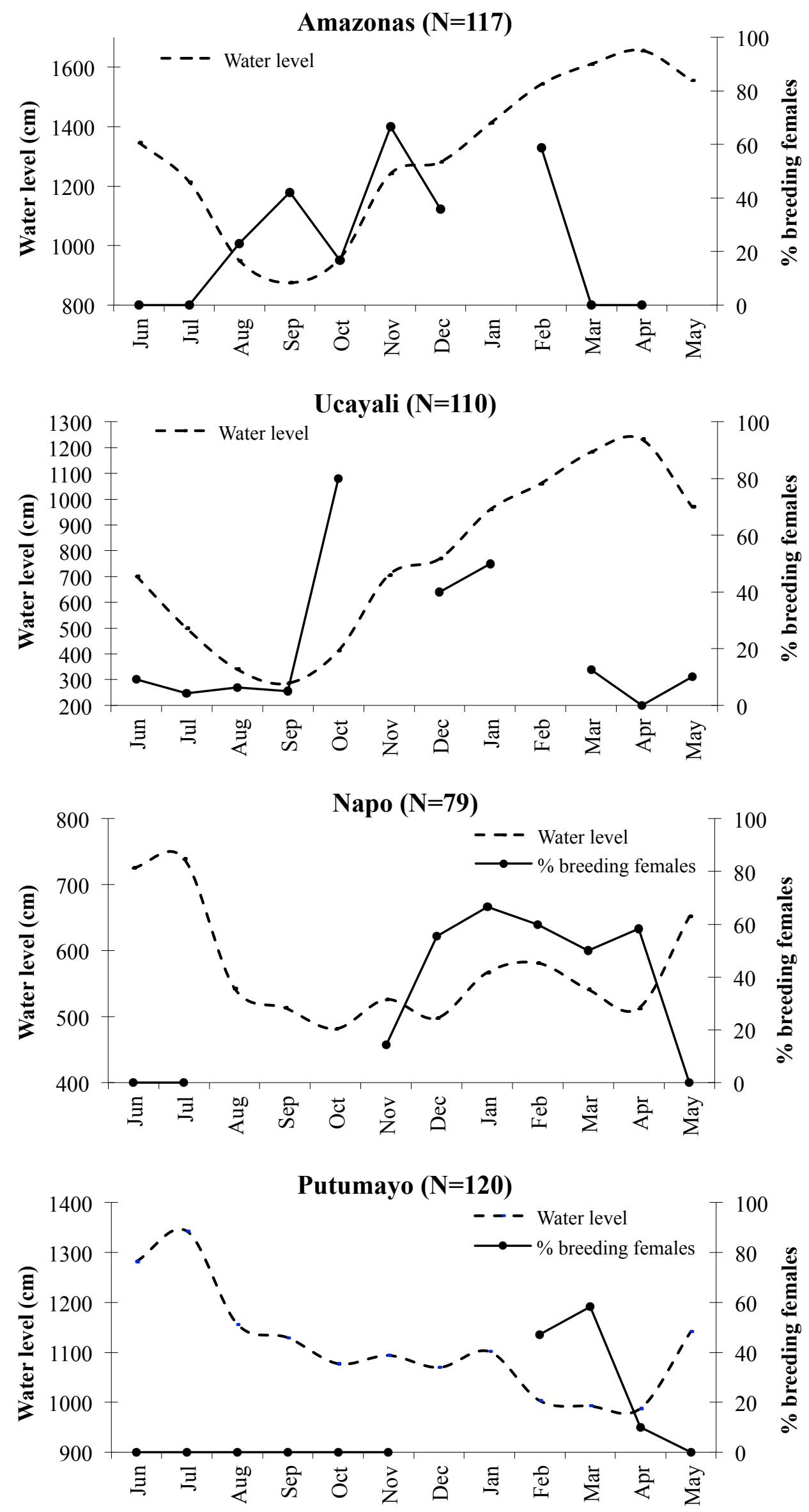

Fig. 6 
Amazonas

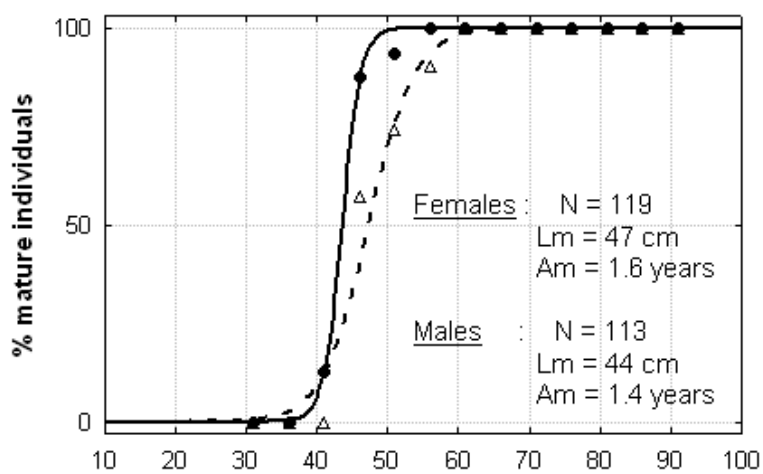

Napo

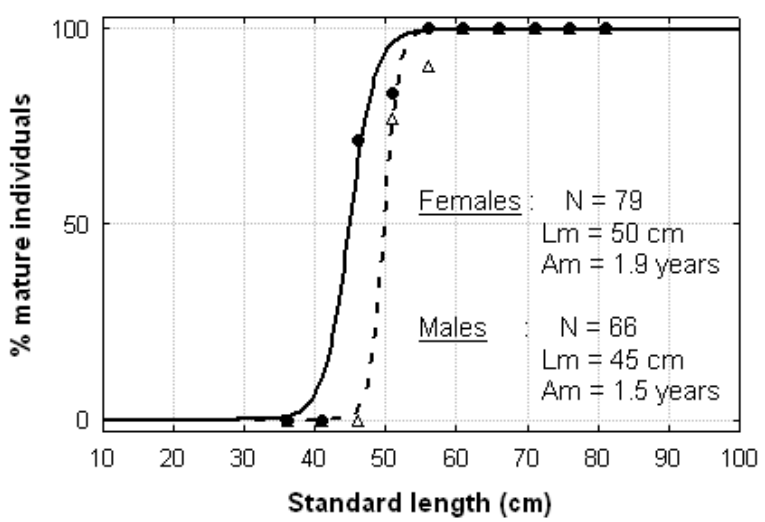

Fig. 7
Ucayali

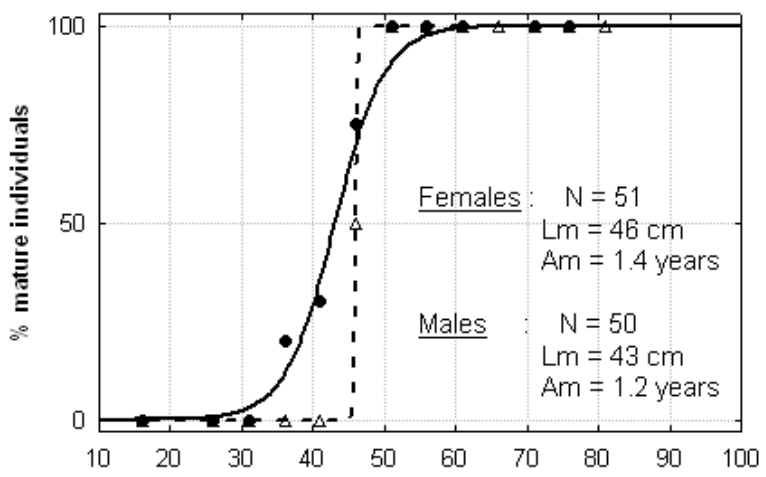

Putumayo

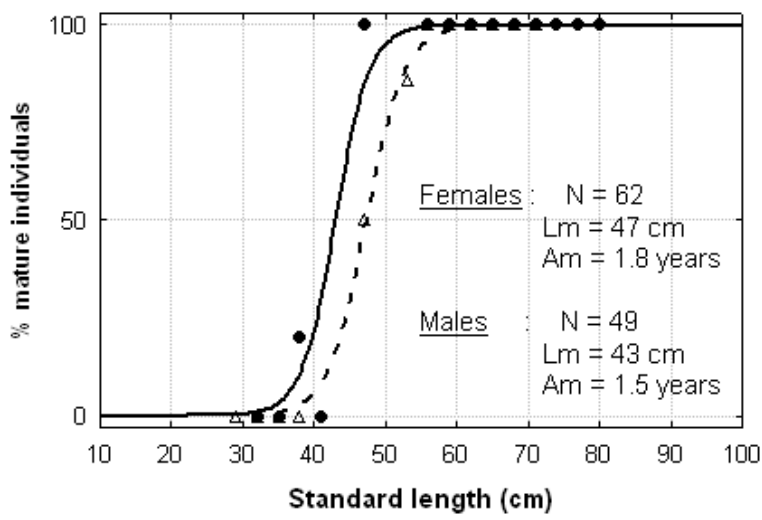




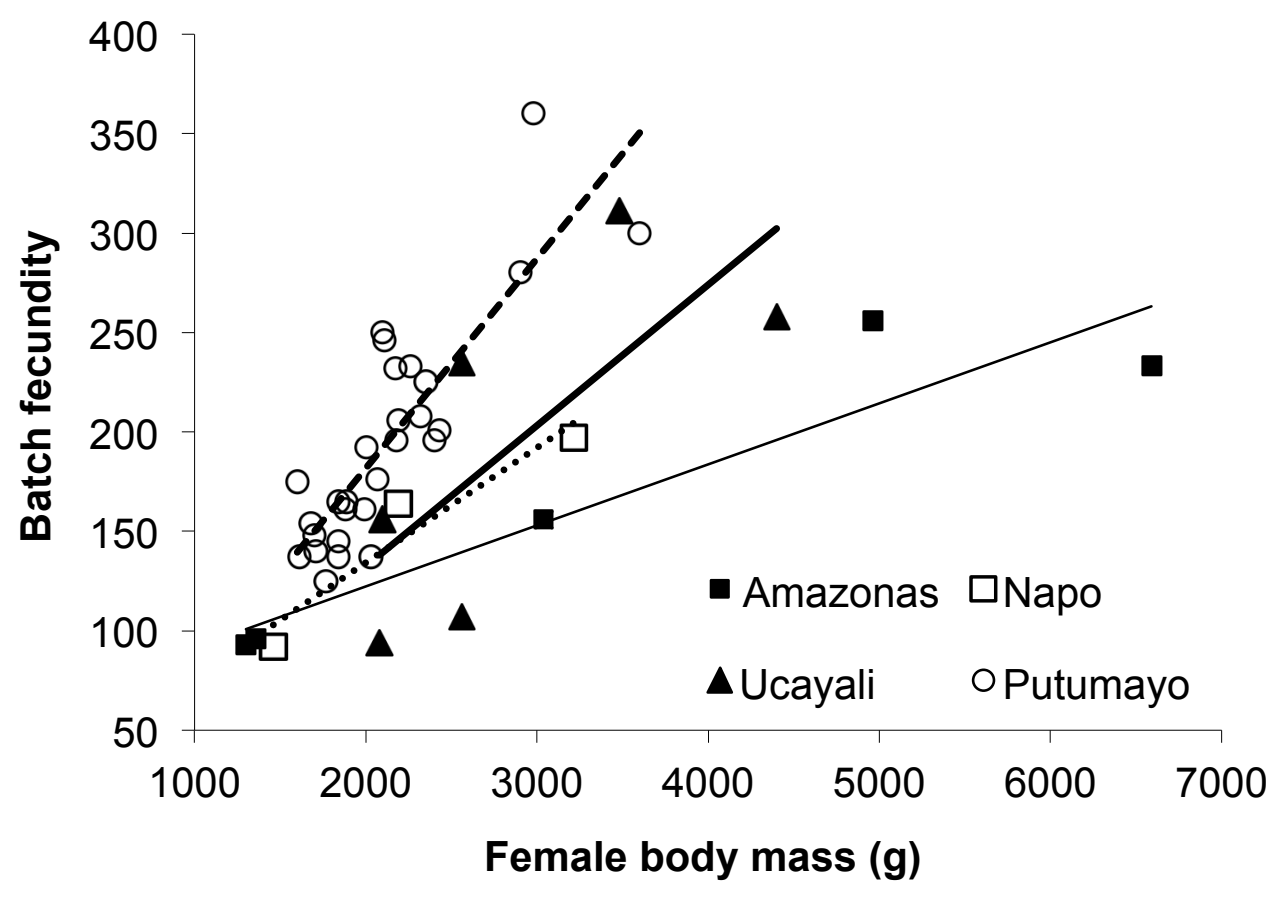

Fig. 8 
Table 1.

\begin{tabular}{lllll}
\hline \multirow{2}{*}{ Female body mass (g) } & \multicolumn{4}{c}{ Batch fecundity } \\
& Amazonas & Napo & Ucayali & Putumayo \\
\hline \multirow{2}{*}{1500} & 107 & 105 & 97 & 129 \\
2500 & 138 & 163 & 168 & 234 \\
3500 & 168 & 221 & 239 & 340 \\
\hline
\end{tabular}

Table 2.

\begin{tabular}{lcccc}
\hline & $\begin{array}{c}\text { Amazonas } \\
(\mathrm{N}=5)\end{array}$ & $\begin{array}{c}\text { Napo } \\
(\mathrm{N}=3)\end{array}$ & $\begin{array}{c}\text { Ucayali } \\
(\mathrm{N}=6)\end{array}$ & $\begin{array}{c}\text { Putumayo } \\
(\mathrm{N}=28)\end{array}$ \\
\hline $\begin{array}{l}\text { Relative fecundity } \\
\text { Oocyte diameter }\end{array}$ & $\begin{array}{l}56 \pm 15 \\
\text { Oocyte mass }\end{array}$ & $66 \pm 7$ & $67 \pm 22$ & $91 \pm 14$ \\
& $0.67 \pm 0.05$ & $10.6 \pm 0.36$ & $11.8 \pm 1.46$ & $12.2 \pm 0.95$ \\
& & $0.64 \pm 0.01$ & $0.77 \pm 0.17$ & $0.89 \pm 0.24$ \\
\hline
\end{tabular}

